\title{
ASSESSMENT OF HEAVY METALS IN SELECTED PERSONAL CARE PRODUCTS IN AKURE METROPOLIS, NIGERIA AND RISK FOR HUMAN HEALTH
}

\author{
Abata, E. O, Akinwamide, A. J; Oyekanmi, K. C; Makinde, S.A \\ Department of Chemistry \\ School of Science \\ Federal University of Technology, Akure, Nigeria.
}

\begin{abstract}
This study was undertaken in order to determine the concentration of heavy metals in selected personal care products purchased within Akure city, Nigeria. It was undertaken to make a comparative metal composition in personal care products with information reported in different literature. Samples were anlysed for heavy metals using Atomic Absorption Spectroscopy (AAS) after dry ashing. The mean concentration was analysed in the samples for $\mathrm{Cr}, \mathrm{Cd}, \mathrm{Co}, \mathrm{Mn}, \mathrm{Zn}, \mathrm{Ni}, \mathrm{Pb}$, and $\mathrm{Cu}$ while also the estimated daily intake and health risk index are considered. The concentration of $\mathrm{Mn}$ in face powder samples has the highest with a range of ND (not detected) to $3.30 \mathrm{mg} / \mathrm{kg}$ followed by $\mathrm{Zn}$ concentration with a range of 0.35 to $0.47 \mathrm{mg} / \mathrm{kg}$. Metals of $\mathrm{Pb}, \mathrm{Ni}, \mathrm{Cr}$, and $\mathrm{Cd}$ were not detected for most of the samples, while the concentration of Mn $\mathrm{Cu}$ and $\mathrm{Zn}$ were detected mostly with a mean concentration of $\mathrm{Mn}$ ranging from ND to 0.37 $\mathrm{mg} / \mathrm{kg}$ for eye pencil samples, 0.04 to $0.13 \mathrm{mg} / \mathrm{kg}$ for soap samples, and 0.05 to $0.07 \mathrm{mg} / \mathrm{kg}$. The possible effects of metals have both acute and chronic effects and this has called for the continual need of government agencies to regulate the toxic metals in consumer products including personal care products.
\end{abstract}

Key Words: Personal Care Products, Health Risk Index, Oral Reference Doses, Heavy Metals, Atomic Absorption Spectroscopy

\section{INTRODUCTION}

Over the centuries, Humans have been more sensitive and conscious of their appearance and their appeal toward themselves and others which has imbibed into Humans of the deliberate consciousness to take care of itself and in this event, exposure to different matter which has different level of dangers can occur, that is in the search to improve and be improved. Humans' self-consciousness span through to the physical appearance in need to look healthier, appear young (and younger if possible), looking attractive and so on. These every day needs over the years have given birth to personal care products [1] which are used varyingly in quantity depending on the individual, the standard of living, location, race, culture, and religion.

Personal care products are consumer products used in personal hygiene and for beautification, these include shampoo, facial treatments, toothpaste, toilet paper, shaving cream, moisturizer, talcum powder, facial cleanser, hand soap, makeup, lotion, lip balm, lipstick, lip gloss, hair clippers, facial tissue, eyeliner, deodorant, cotton pads and so on [2-3]. Personal care products (PCP) have contributed to the level of metal intake into the body and some of the products contain heavy metals as its components and these metals are usually dangerous when accumulation occurs. Heavy metals such as chromium has been described to have its $\mathrm{Cr}(\mathrm{VI})$ to be more toxic and more mobile (with labile centre) than trivalent chromium which is inert and in biological $\mathrm{pH}$ its trivalent undergoes precipitation as hydroxide while its hexavalent chromium remains in the solution [4], $\mathrm{Cr}$ is associated with allergic dermatitis[5] and Chromium hydroxide $\left[\mathrm{Cr}_{2} \mathrm{O}(\mathrm{OH})_{4}\right]$ and chromium oxide $\left[\mathrm{Cr}_{2} \mathrm{O}_{3}\right]$ are used as colouring agents in cosmetic products such as eye shadow [6]. Eye cosmetics such as eye pencils have been identified as a suspected source of $\mathrm{Pb}$ exposure to the ocular system in a number of adults and children. The use of leaded eye cosmetics has been observed to be strongly correlated with elevated blood $\mathrm{Pb}$ levels [7]. Cd metal gets absorbed by humans which will accumulate inside the body throughout life. Lead is an extremely toxic heavy metal that disturbs various plant physiological processes and unlike other metals, such as zinc, copper, and manganese, it does not play any 


\section{International Journal of Engineering Applied Sciences and Technology, 2020 Vol. 5, Issue 7, ISSN No. 2455-2143, Pages 218-226 \\ Published Online November 2020 in IJEAST (http://www.ijeast.com)}

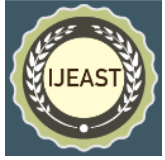

biological functions. Heavy metals contamination may occur through different means such as through diet, from medications, from the environment [8]. Dermal exposure has been suggested to be the most significant route because most of the cosmetics products are directly applied to the skin [9]. Oral exposure can occur from wearing cosmetics products containing heavy metal impurities around the mouth and also from hand to mouth contact [6]. The Heavy metal ions which come in contact with the human body, get absorbed and form complexes with carboxylic acid ($\mathrm{COOH})$, amine $\left(-\mathrm{NH}_{2}\right)$, and thiol $(-\mathrm{SH})$ of proteins resulting in malfunctioning or death of the cells and consequently lead to various diseases[10]. The toxicity of metal ions to human systems is due to the chemical reactivity of the ions with cellular structural proteins, enzymes and membrane systems. Toxicity of a specific metal occurs in organs that accumulate the highest concentration of the metals, which is often dependent on the route of exposure and the chemical compound of the metal which will lead to the formation of a complex compound. The treatment of metal intoxication is achieved by using chelation therapy that binds with the metal ions and the complexes are then eliminated from the body [11]. The skin absorption of salt of heavy metals varies with different parameters [12]. Metals have been shown to causes acute as well as chronic poisoning in humans and other experimental animals. Cadmium and cadmium compounds are known human carcinogens. Ingesting very high levels severely irritates the stomach, leading to vomiting and diarrhea [13]. Cadmium in the environment is toxic to plants and animals and many micro-organisms. Manganese can be regarded as an essential metal for the body but the introduction of methylcyclopentadienyl manganese tricarbonyl (MMT) as a gasoline additive became world concerns. MMT has been linked with the development of Parkinson's disease-like syndrome. Exposure to elevated levels of manganese can result in Manganism (neurotoxicity), characterized by rigidity, tremor, a mask-like expression, gait disturbances, bradykinesia, micrographia, memory and cognitive dysfunction, and mood disorder. The symptoms of manganism are very similar to that of Parkinson's disease. [14]. The consequence of $\mathrm{Cu}$ accumulation leads to Wilson's disease and is generally ascribed to $\mathrm{Cu}$-induced oxygen radical-mediated damage [15-16].

In a report by Health Canada on cosmetic products, $100 \%$ of all products subjected to test, tested positive for nickel and over $90 \%$ tested positive for both lead and beryllium [17]. They report at least 4 of the 8 metals of concern (arsenic, cadmium, lead, mercury, beryllium, nickel, selenium, and thallium) on average.
Furthermore, Health Canada listed metals such as Ar, $\mathrm{Pb}$, and $\mathrm{Hg}$ as being banned and some restricted such as aluminum, also Health Canada defined guidelines on heavy metal impurities in cosmetics products with specificity in limit of $1 \mathrm{mg} / \mathrm{kg}$ for mercury, $10 \mathrm{mg} / \mathrm{kg}$ for Lead and $3 \mathrm{mg} / \mathrm{kg}$ for arsenic [17]. The German Federal Government also reported on metal contents in various cosmetic products and metal levels as an impurity in cosmetic products were given a limit of 5 $\mathrm{mcg} / \mathrm{g}$ for As, $1 \mathrm{mcg} / \mathrm{g}$ for $\mathrm{Hg}, 20 \mathrm{mcg} / \mathrm{g}$ for $\mathrm{Pb}$. [18]. Due to the toxicity level been known, the US FDA[19] puts a ban on nine ingredients which include coal tar colors, bithionol, chlorofluorocarbons propellants, chloroform, halogenated salicylanilides, hexachlorophen, methylene chloride, vinyl chloride, zirconium containing complexes, mercury, and sunscreeen in cosmetic products, also Directive 76/768/EEC banned the use of heavy metals, Cd, Co, $\mathrm{Cr}, \mathrm{Ni}$, and $\mathrm{Pb}$ as impurities in the preparation of cosmetics [20].

PCPs contain different level of heavy metals, even though research has shown various result but new batches of these products have always been produced with improved and totally new products claiming specific care, also combination of these products usage can lead to increase of heavy metal intake through different surface of the body thus accumulating the percentage in the body which can lead to issues and complication to human health. Furthermore, since it is hard to keep track of the safety of all personal care products a continual check of products is of necessity. Thus this study is aimed at the determination of heavy metals present in selected personal care products which are used in Akure, Ondo State, Nigeria, and to determine the estimated daily intake of these metals in each selected PCPs.

\section{MATERIALS AND METHODOLOGY}

\section{Sample collections}

Eighteen cosmetics (PCPs) samples inform of eye pencils, makeup powders, soaps, and detergents were bought from stores and various shops in the Oja Oba market, Akure, Nigeria.

Reagents and chemicals used were distilled water, Analytical grade nitric acid (95\%) and perchloric acid (70\%), 10\% nitric acid and $1 \mathrm{M}$ nitric acid.

\section{Sample preparation}

Glassware and plastic were washed, rinsed with tap water and soaked in $5 \% \mathrm{HNO}_{3}$ solution for 24 hours. They were then rinsed with distilled water. The samples were each oven-dried to a constant weight and 


\section{International Journal of Engineering Applied Sciences and Technology, 2020 \\ Vol. 5, Issue 7, ISSN No. 2455-2143, Pages 218-226 \\ Published Online November 2020 in IJEAST (http://www.ijeast.com)}

$0.2 \mathrm{~g}$ each was weighed into porcelain crucible, it was pre-ashed on a hot plate in the fume hood to eliminate most of its organic contents, before been dry-ashed in a muffle furnace by a stepwise increase of temperature to $550^{\circ} \mathrm{C}$ for several hours [21]. The ashed samples were cooled and $5 \mathrm{ml}$ of $1 \mathrm{M} \mathrm{HNO}_{3}$ was added, diluted to $50 \mathrm{ml}$ and filtered through Whatman No. 42 into sample bottles ready for analysis this process was done in triplicate for each sample.

\section{SAMPLE ANALYSIS}

All samples were analysed in triplicate with Atomic Absorption Spectroscopy for Cadmium, Nickel, Lead, Manganese, Copper, Zinc, Cobalt, and Chromium using BUCK SCIENTIFIC model 210 (AAS).

Table 1 sample ID used in this study

\begin{tabular}{llll}
\hline Face powders(makeups) & Eye pencils & Soaps & detergents \\
\hline P1 & E1 & S1 & D1 \\
P2 & E2 & S2 & D2 \\
P3 & E3 & S3(medicated) & \\
P4 & E4 & S4(medicated) & \\
P5 & E5 & & \\
P6 & E6 & & \\
\hline
\end{tabular}

\section{STATISTICAL ANALYSIS}

Data collected were tabulated and anlysed using SPSS version 22.0 to find a statistical difference between the concentrations of the element, one-way ANOVA was applied at a 95\% confidence level.

\section{RISK ASSESSMENT}

Risk assessment of metal-contaminated cosmetic products to human health was characterized by estimated daily intake (EDI) which is expressed in $\mathrm{mg} / \mathrm{kg} / \mathrm{day}$ and health risk index (HRI). The estimated daily intake (EDI) was calculated to estimate the daily metal intake by the body system of specified bodyweight of a consumer, the EDI was calculated using the following formula [22-24].

$$
E D I=\frac{C \times \mathrm{D} f}{\mathrm{BW}}
$$

Where EDI is the estimated daily of metals $(\mathrm{mg} / \mathrm{kg} /$ day $) ; \mathrm{C}$ is the concentration of the metal under consideration in $(\mathrm{mg} / \mathrm{kg}) ; \mathrm{D}_{\mathrm{f}}$ is the daily intake of a fraction of cosmetic products and BW is the body weight $(\mathrm{kg})$ which is taken to be $70 \mathrm{~kg}$ in this study. The HRI was calculated from the EDI of metals and Reference Oral Dose (RfD). The $\mathrm{R}_{\mathrm{f}} \mathrm{D}$ is an estimated exposure of metal to the human body per day that has no effect during lifetime [23]. The formula below was used to calculate the HRI.

$$
H R I=\frac{E D I}{R f D}
$$

The value of oral reference doses (RfD) for the heavy metals considered in this study are summarized in Table $2[23,25]$. The values of $D_{f}$ used were derived from SCCS (Scientific Committee on Consumer Safety)[26].

Table 2 Reference Oral Doses for selected metals

\begin{tabular}{lllll}
\hline Heavy metals & $\mathrm{Cr}$ & $\mathrm{Cu}$ & $\mathrm{Mn}$ & $\mathrm{Zn}$ \\
\hline $\mathrm{RfD}$ & 1.5 & 0.04 & 0.005 & 0.3 \\
$(\mathrm{mg} / \mathrm{kg} /$ day $)$ & & & & \\
\hline
\end{tabular}

\section{RESULT AND DISCUSSION}

The mean concentration (mean \pm standard deviation) of heavy metals in face powders $(\mathrm{P})$, eye pencils $(\mathrm{E})$, soap (S) and detergents (D) samples are presented respectively in table $3,4,5$ and 6.

Table 3 Mean concentration (mean \pm standard deviation) of heavy metals in selected face powder samples

\begin{tabular}{lllllll}
\hline SAMPLES & P1 & P2 & P3 & P4 & P5 & P6 \\
\hline Mn (mg/kg) & ND & $3.30 \pm 0.019$ & ND & ND & $1.24 \pm 0.036$ & $3.30 \pm 0.152$ \\
\hline
\end{tabular}




\begin{tabular}{lllllll}
\hline $\mathrm{Cu}(\mathrm{mg} / \mathrm{kg})$ & $\mathrm{ND}$ & $0.14 \pm 0.004$ & $0.13 \pm 0.005$ & $\mathrm{ND}$ & $\mathrm{ND}$ & $0.14 \pm 0.019$ \\
$\mathrm{Zn}(\mathrm{mg} / \mathrm{kg})$ & $\mathrm{ND}$ & $0.81 \pm 0.056$ & $\mathrm{ND}$ & $\mathrm{ND}$ & $\mathrm{ND}$ & $0.76 \pm 0.058$ \\
$\mathrm{Co}(\mathrm{mg} / \mathrm{kg})$ & $\mathrm{ND}$ & $\mathrm{ND}$ & $\mathrm{ND}$ & $\mathrm{ND}$ & $\mathrm{ND}$ & $\mathrm{ND}$ \\
$\mathrm{Cr}(\mathrm{mg} / \mathrm{kg})$ & $\mathrm{ND}$ & $0.1715 \pm 0.0085$ & $\mathrm{ND}$ & $\mathrm{ND}$ & $\mathrm{ND}$ & $\mathrm{ND}$ \\
$\mathrm{Cd}(\mathrm{mg} / \mathrm{kg})$ & $\mathrm{ND}$ & $\mathrm{ND}$ & $\mathrm{ND}$ & $\mathrm{ND}$ & $\mathrm{ND}$ & $\mathrm{ND}$ \\
$\mathrm{Pb}(\mathrm{mg} / \mathrm{kg})$ & $\mathrm{ND}$ & $\mathrm{ND}$ & $\mathrm{ND}$ & $\mathrm{ND}$ & $\mathrm{ND}$ & $\mathrm{ND}$ \\
$\mathrm{Ni}(\mathrm{mg} / \mathrm{kg})$ & $\mathrm{ND}$ & $\mathrm{ND}$ & $\mathrm{ND}$ & $\mathrm{ND}$ & $\mathrm{ND}$ & $\mathrm{ND}$ \\
& & & & & &
\end{tabular}

ND- not detected

Table 4 Mean concentration (mean \pm standard deviation) of heavy metals in selected eye pencil samples

\begin{tabular}{lllllll}
\hline SAMPLES & E1 & E2 & E3 & E4 & E5 & E6 \\
\hline $\mathrm{Mn}(\mathrm{mg} / \mathrm{kg})$ & $\mathrm{ND}$ & $0.33 \pm 0.043$ & $0.37 \pm 0.020$ & $\mathrm{ND}$ & $\mathrm{ND}$ & $0.05 \pm 0.005$ \\
$\mathrm{Cu}(\mathrm{mg} / \mathrm{kg})$ & $\mathrm{ND}$ & $\mathrm{ND}$ & $0.12 \pm 0.009$ & $\mathrm{ND}$ & $\mathrm{ND}$ & $0.05 \pm 0.001$ \\
$\mathrm{Zn}(\mathrm{mg} / \mathrm{kg})$ & $0.07 \pm 0.008$ & $0.72 \pm 0.056$ & $0.65 \pm 0.051$ & $0.03 \pm 0.014$ & $0.04 \pm 0.004$ & $0.19 \pm 0.005$ \\
$\mathrm{Co}(\mathrm{mg} / \mathrm{kg})$ & $\mathrm{ND}$ & $\mathrm{ND}$ & $\mathrm{ND}$ & $\mathrm{ND}$ & $\mathrm{ND}$ & $\mathrm{ND}$ \\
$\mathrm{Cr}(\mathrm{mg} / \mathrm{kg})$ & $\mathrm{ND}$ & $\mathrm{ND}$ & $\mathrm{ND}$ & $\mathrm{ND}$ & $\mathrm{ND}$ & $\mathrm{ND}$ \\
$\mathrm{Cd}(\mathrm{mg} / \mathrm{kg})$ & $\mathrm{ND}$ & $\mathrm{ND}$ & $\mathrm{ND}$ & $\mathrm{ND}$ & $\mathrm{ND}$ & $\mathrm{ND}$ \\
$\mathrm{Pb}(\mathrm{mg} / \mathrm{kg})$ & $\mathrm{ND}$ & $\mathrm{ND}$ & $\mathrm{ND}$ & $\mathrm{ND}$ & $\mathrm{ND}$ & $\mathrm{ND}$ \\
$\mathrm{Ni}(\mathrm{mg} / \mathrm{kg})$ & $\mathrm{ND}$ & $\mathrm{ND}$ & $\mathrm{ND}$ & $\mathrm{ND}$ & $\mathrm{ND}$ & $\mathrm{ND}$ \\
\hline
\end{tabular}

ND-not detected

Table 5 Mean concentration (mean \pm standard deviation) of heavy metals in selected soap samples

\begin{tabular}{lllll}
\hline SAMPLES & $\mathrm{S} 1$ & $\mathrm{~S} 2$ & $\mathrm{~S} 3$ & $\mathrm{~S} 4$ \\
\hline $\mathrm{Mn}(\mathrm{mg} / \mathrm{kg})$ & $0.04 \pm 0.006$ & $0.07 \pm 0.005$ & $0.13 \pm 0.004$ & $0.09 \pm 0.006$ \\
$\mathrm{Cu}(\mathrm{mg} / \mathrm{kg})$ & $0.03 \pm 0.004$ & $0.05 \pm 0.001$ & $0.12 \pm 0.002$ & $0.18 \pm 0.010$ \\
$\mathrm{Zn}(\mathrm{mg} / \mathrm{kg})$ & $0.16 \pm 0.011$ & $0.21 \pm 0.003$ & $0.64 \pm 0.006$ & $0.23 \pm 0.014$ \\
$\mathrm{Co}(\mathrm{mg} / \mathrm{kg})$ & $\mathrm{ND}$ & $\mathrm{ND}$ & $\mathrm{ND}$ & $\mathrm{ND}$ \\
$\mathrm{Cr}(\mathrm{mg} / \mathrm{kg})$ & $\mathrm{ND}$ & $\mathrm{ND}$ & $\mathrm{ND}$ & $\mathrm{ND}$ \\
$\mathrm{Cd}(\mathrm{mg} / \mathrm{kg})$ & $\mathrm{ND}$ & $\mathrm{ND}$ & $\mathrm{ND}$ & $\mathrm{ND}$ \\
$\mathrm{Pb}(\mathrm{mg} / \mathrm{kg})$ & $\mathrm{ND}$ & $\mathrm{ND}$ & $\mathrm{ND}$ & $\mathrm{ND}$ \\
$\mathrm{Ni}(\mathrm{mg} / \mathrm{kg})$ & $\mathrm{ND}$ & $\mathrm{ND}$ & $\mathrm{ND}$ & $\mathrm{ND}$ \\
\hline
\end{tabular}


$\mathrm{ND}$ - not detected

Table 6 Mean concentration (mean \pm standard deviation) of heavy metals in selected detergents samples

\begin{tabular}{lll}
\hline SAMPLES & D1 & D2 \\
\hline $\mathrm{Mn}(\mathrm{mg} / \mathrm{kg})$ & $0.07 \pm 0.010$ & $0.05 \pm 0.006$ \\
$\mathrm{Cu}(\mathrm{mg} / \mathrm{kg})$ & $0.05 \pm 0.006$ & $0.05 \pm 0.003$ \\
$\mathrm{Zn}(\mathrm{mg} / \mathrm{kg})$ & $0.09 \pm 0.003$ & $0.14 \pm 0.005$ \\
$\mathrm{Co}(\mathrm{mg} / \mathrm{kg})$ & $\mathrm{ND}$ & $\mathrm{ND}$ \\
$\mathrm{Cr}(\mathrm{mg} / \mathrm{kg})$ & $\mathrm{ND}$ & $\mathrm{ND}$ \\
$\mathrm{Cd}(\mathrm{mg} / \mathrm{kg})$ & $\mathrm{ND}$ & $\mathrm{ND}$ \\
$\mathrm{Pb}(\mathrm{mg} / \mathrm{kg})$ & $\mathrm{ND}$ & $\mathrm{ND}$ \\
$\mathrm{Ni}(\mathrm{mg} / \mathrm{kg})$ & $\mathrm{ND}$ & $0.1455 \pm 0.00808$ \\
\hline
\end{tabular}

ND- not detected

Calculated Estimated daily intake (EDI) for each metals concentration detected in each sample and the health risk index (HRI) of each metals are presented intable 7 and table 8 respectively.

Table 7 Estimated Daily Intake (EDI)

\begin{tabular}{lllllllll}
\hline Samples & $\mathrm{Cd}$ & $\mathrm{Co}$ & $\mathrm{Cr}$ & $\mathrm{Cu}$ & $\mathrm{Mn}$ & $\mathrm{Ni}$ & $\mathrm{Pb}$ & $\mathrm{Zn}$ \\
\hline P1 & - & - & - & - & - & - & - & - \\
P2 & - & - & $1.25 \times 10^{-6}$ & $1.02 \times 10^{-6}$ & $2.40 \times 10^{-5}$ & - & - & $5.9 \times 10^{-6}$ \\
P3 & - & - & - & $9.47 \times 10^{-7}$ & - & - & - & - \\
P4 & - & - & - & - & - & - & - & - \\
P5 & - & - & - & - & $9.03 \times 10^{-6}$ & - & - & - \\
P6 & - & - & - & $1.02 \times 10^{-6}$ & $2.40 \times 10^{-5}$ & - & - & $5.54 \times 10^{-6}$ \\
E1 & - & - & - & - & - & - & - & $5.0 \times 10^{-9}$ \\
E2 & - & - & - & - & $2.36 \times 10^{-8}$ & - & - & $5.14 \times 10^{-8}$ \\
E3 & - & - & - & $8.57 \times 10^{-9}$ & $2.64 \times 10^{-8}$ & - & - & $4.64 \times 10^{-8}$ \\
E4 & - & - & - & - & - & - & $2.14 \times 10^{-9}$ \\
E5 & - & - & - & - & - & - & - \\
E6 & - & - & - & $3.57 \times 10^{-9}$ & $3.57 \times 10^{-9}$ & - & - & $1.36 \times 10^{-9}$ \\
S1 & - & - & - & $8.14 \times 10^{-8}$ & $1.09 \times 10^{-7}$ & - & - & $4.34 \times 10^{-7}$ \\
S2 & - & - & - & $1.36 \times 10^{-7}$ & $1.9 \times 10^{-7}$ & - & - & $5.70 \times 10^{-7}$ \\
S3 & - & - & - & $3.26 \times 10^{-7}$ & $3.53 \times 10^{-7}$ & - & - & $1.74 \times 10^{-6}$ \\
S4 & - & - & - & $4.89 \times 10^{-7}$ & $2.44 \times 10^{-7}$ & - & - & $6.24 \times 10^{-7}$ \\
\hline
\end{tabular}

Table 8 Health Risk Index (HRI)

\begin{tabular}{lllllllll}
\hline Samples & $\mathrm{Cd}$ & $\mathrm{Co}$ & $\mathrm{Cr}$ & $\mathrm{Cu}$ & $\mathrm{Mn}$ & $\mathrm{Ni}$ & $\mathrm{Pb}$ & $\mathrm{Zn}$ \\
\hline P1 & - & - & - & - & - & - & - & - \\
P2 & - & - & $8.0 \times 10^{-7}$ & $3.0 \times 10^{-5}$ & $4.81 \times 10^{-3}$ & - & - & $2.0 \times 10^{-5}$ \\
P3 & - & - & - & $2.0 \times 10^{-5}$ & - & - & - & - \\
P4 & - & - & - & - & - & - & - & - \\
P5 & - & - & - & - & $1.81 \times 10^{-3}$ & - & - & - \\
P6 & - & - & - & $3.0 \times 10^{-5}$ & $4.81 \times 10^{-3}$ & - & - & $2.0 \times 10^{-5}$ \\
\hline
\end{tabular}




\section{International Journal of Engineering Applied Sciences and Technology, 2020 Vol. 5, Issue 7, ISSN No. 2455-2143, Pages 218-226 \\ Published Online November 2020 in IJEAST (http://www.ijeast.com)}

\begin{tabular}{|c|c|c|c|c|c|c|c|c|}
\hline E1 & - & - & - & - & - & - & - & $2.0 \times 10^{-8}$ \\
\hline E2 & - & - & - & - & $4.71 \times 10^{-6}$ & - & - & $2.0 \times 10^{-7}$ \\
\hline E3 & - & - & - & $2.0 \times 10^{-7}$ & $5.29 \times 10^{-6}$ & - & - & $2.0 \times 10^{-7}$ \\
\hline E4 & - & - & - & - & - & - & - & $7.0 \times 10^{-9}$ \\
\hline E5 & - & - & - & - & - & - & - & $1.0 \times 10^{-8}$ \\
\hline E6 & - & - & - & $9.0 \times 10^{-8}$ & $7.14 \times 10^{-7}$ & - & - & $5.0 \times 10^{-8}$ \\
\hline S1 & - & - & - & $2.0 \times 10^{-6}$ & $2.17 \times 10^{-5}$ & - & - & $1.0 \times 10^{-6}$ \\
\hline S2 & - & - & - & $3.0 \times 10^{-6}$ & $3.80 \times 10^{-5}$ & - & - & $2.0 \times 10^{-6}$ \\
\hline S3 & - & - & - & $8.0 \times 10^{-6}$ & $7.06 \times 10^{-5}$ & - & - & $6.0 \times 10^{-6}$ \\
\hline S4 & - & - & - & $1.0 \times 10^{-5}$ & $4.89 \times 10^{-5}$ & - & - & $2.0 \times 10^{-6}$ \\
\hline
\end{tabular}

\section{DISCUSSION}

From Table 3 the metals present in the face powder in this study are Manganese, Copper, Zinc, and Chromium while sample P1 and P4 having no detected metals. The mean concentration of Mn shows the highest concentration between the four metals detected. The mean concentration of Mn ranges from ND to $3.30 \mathrm{mg} / \mathrm{kg}$, a related study by Ali (2016)[27] shows a mean concentration of $27.45 \mathrm{mk} / \mathrm{kg}$ for the high price powder and $21.08 \mathrm{mk} / \mathrm{kg}$ for low price powders which is relatively high compared to the mean concentration in this study. The Mn mean concentration of sample P5 is significantly different at $(p<0.05)$ level of significance. The present of Mn can be a result of the use of gluconolactone containing manganese which is used as a skin conditioning agent [28]. The toxicology effect of Manganese has been said to possess Parkinson's disease-like syndrome with tremor, gait disorder, postural disability and cognitive disorder [14]. The concentration of $\mathrm{Cu}$ ranges from ND to $0.14 \mathrm{mg} / \mathrm{kg}$, the detected metals are in sample P2, P3, and P6. A study by Ullah et al (2017)[10] showed a mean concentration with a range of $1.095 \mathrm{mg} / \mathrm{kg}$ to $1.515 \mathrm{mg} / \mathrm{kg}$ and Ali (2016)[27] reported a mean concentration of $4.24 \mathrm{mg} / \mathrm{kg}$ and 6.78 , the use of copper in copper powder as ingredient to impart brown colour to which the powders in this study has various shade of brown colour can be the source of $\mathrm{Cu}$ in the face powder make-ups, and the acute poisoning of $\mathrm{Cu}$ can cause temporary gastrointestinal distress with symptoms such as nausea, vomiting, while high level of exposure to $\mathrm{Cu}$ can cause destruction of red blood cells, damage to the liver and kidney [29]. The mean concentration of $\mathrm{Zn}$ ranges from ND to $0.81 \mathrm{mg} / \mathrm{kg}, \mathrm{Zn}$ is detected in sample P2 and P6, Zn mean concentration reported by Ullah et al. (2017) [10] ranges from 1.818 to $1067 \mathrm{mg} / \mathrm{kg}$. The detection of $\mathrm{Zn}$ in these samples can be as a result of $\mathrm{ZnO}$ used as a key sunscreen ingredient [28]. Accumulation of $\mathrm{Zn}$ may result in pain, muscular stiffness and irritability [30-31]. The mean concentration of the detected metals in sample P2 and
P6 showed a close range in each metal, this may indicate similar ingredients being used in their production. Chromium with a mean concentration of $0.1715 \mathrm{mg} / \mathrm{kg}$ is detected in sample P2 which is significantly different at $(\mathrm{p}<0.05)$ level of significance. Report from Ullah et al. (2017) [10] had a mean concentration with range of ND to $0.262 \mathrm{mg} / \mathrm{kg}$ in powder, also Nnorom (2011) [32] reported a mean concentration with a range of ND to $2.7 \mathrm{mg} / \mathrm{kg}$ while Ali (2016) [27] reported a mean concentration of $0.012 \mathrm{mg} / \mathrm{kg}$ for high price powders. Cr may be from chromium oxide or chromium hydroxide [28] used as a pigment. $\mathrm{Cr}$ has been said to be associated with allergic dermatitis in humans [5].

The mean concentrations of metals analysed in the eye pencils are shown in Table 4, it showed that only $\mathrm{Cu}$, $\mathrm{Mn}$ and $\mathrm{Zn}$ are present out of the eight metals, the concentration of $\mathrm{Cu}$ in the eye pencils ranges from ND to $0.12 \mathrm{mg} / \mathrm{kg}$ while the mean concentration of $\mathrm{Mn}$ ranges from $0.05 \mathrm{mg} / \mathrm{kg}$ to $0.37 \mathrm{~g} / \mathrm{kg}$ and that of $\mathrm{Zn}$ ranges from 0.03 to $0.72 \mathrm{mk} / \mathrm{kg}$. The detected metals obtained by Nnorom et al. (2005) [33] include Pb, Cd, $\mathrm{Cr}, \mathrm{Ni}$, and $\mathrm{Zn}$, the mean concentration. The use of manganese violet as colour pigment might be the source of $\mathrm{Mn}$ in the eye pencils samples [28]. It was reported by Nnorom et al. (2005) [33] on eye pencils containing $\mathrm{Pb}, \mathrm{Cd}, \mathrm{Cr}, \mathrm{Ni}$, and $\mathrm{Zn}$, the mean concentration reported was with a range of 36.3 to $198.7 \mathrm{mg} / \mathrm{kg}$ which compared to the mean concentration in this study is far too high. The $\mathrm{Zn}$ concentration of E2 and E3 are significantly different at $(\mathrm{p}<0.05)$ level of significance. $\mathrm{Zn}$ may be present as a result of $\mathrm{ZnO}$ which can be used as a bulking agent or colourant [28].

In Table 5, the metals present in the soap samples are $\mathrm{Cu}, \mathrm{Mn}$, and $\mathrm{Zn}$ with $\mathrm{Zn}$ showing the highest mean concentrations. The mean concentration of $\mathrm{Cu}$ in the soap samples ranges from 0.03 to $0.18 \mathrm{mg} / \mathrm{kg}$ which maybe as a result of $\mathrm{Cu}$ in water used during the soap production process or tag along with ingredient of colour. The non-medicated soap samples are S1 and 


\section{International Journal of Engineering Applied Sciences and Technology, 2020 Vol. 5, Issue 7, ISSN No. 2455-2143, Pages 218-226 \\ Published Online November 2020 in IJEAST (http://www.ijeast.com)}

S2 while the medicated soaps are sample S3 and S4. The mean concentration of $\mathrm{Cu}$ in this study for medicated and non-medicated soaps is lower than that obtained for medicated soaps and non-medicated soaps by Ayenimo et al. (2010) [21] which has copper with a mean range of 0.185 to $0.875 \mathrm{mg} / \mathrm{kg}$ and a range 0.103 to $0.516 \mathrm{mg} / \mathrm{kg}$ respectively. Copper is said to be needed because of its serves as components of several enzymes necessary for normal metabolic functions in human it is recommended at a median intake through diet by the US FDA [34] as $0.9 \mathrm{mg}$ per day while the safe highest level intake for an extended period is $10 \mathrm{mg}$ per day but an acute poisoning of $\mathrm{Cu}$ can cause temporary gastrointestinal distress with symptoms such as nausea, vomiting, while high level of exposure to $\mathrm{Cu}$ can cause destruction of red blood cells, damage to the liver and kidney [29]. The mean concentration of $\mathrm{Zn}$ in the soap ranges from 0.16 to $0.64 \mathrm{mg} / \mathrm{kg}$ which is relatively close to that reported by Ayenimo et al. (2010) [21] which ranges from 0.422 to $0.88 \mathrm{mg} / \mathrm{kg}$. Accumulation of zinc is likely to cause inhibition of oxygen and calcium transportation in the body that reduced IQ (intelligent quotient) and learning disability, intrauterine fetal death, low body weight. Due to the oversensitivity of some human, it can cause metal fever (a flu-like condition) which goes away after two days. Zinc can be dangerous to the newborn and unborn through mothers' blood or milk [35]. Zn in the non-medicated soap may be due to the use of zinc ingredients such as zinc sulphate used as cosmetic astringents also zinc pyrithione, zinc phenol sulfonate and zinc acetate [28] are used in inhibiting the growth of microorganism most especially in the medicated soaps. The mean concentration of $\mathrm{Mn}$ in the soap sample ranges from 0.04 to $0.13 \mathrm{mg} / \mathrm{kg}$ which could be a result of impurities such as metal complex formation with some of the ingredients of soap production, such as organic salts of Mn which can be soluble in lipid [14]. Table 6 shows the mean concentration of powdered detergents with $\mathrm{Zn}, \mathrm{Mn}, \mathrm{Cu}$, and $\mathrm{Ni}$ being detected, a similar study on detergent by Sani and Shehu (2018) [36] reported on the detection of $\mathrm{Cr}, \mathrm{Cd}$, $\mathrm{Ni}$, and $\mathrm{Pb}$, where the concentration of $\mathrm{Ni}$ ranges from 1.56 to $7.81 \mathrm{mg} / \mathrm{kg}$ whereas the mean concentration of $\mathrm{Ni}$ in this study ranges from ND to $0.1455 \mathrm{mg} / \mathrm{kg}$. A limit of $0.5 \mathrm{mg} / \mathrm{cm} 2$ per week of nickel release was suggested as a safe limit for nickel exposure [36]. Metals are toxic, causing irritant contact dermatitis, ulceration or granuloma, and contact allergy. Nickel is the most common cause of contact allergy of all skin sanitizer and it is a cause of hand eczema. Sensitivity to nickel is generally caused by direct and prolonged skin contact with items that release nickel ions which are dependent on the amount of Ni per skin unit area [36]. Mn ranges from 0.05 to $0.07 \mathrm{mg} / \mathrm{kg}$, while that of
$\mathrm{Zn}$ ranges from 0.09 to $0.145 \mathrm{mg} / \mathrm{kg}$ and the mean concentration of $\mathrm{Cu}$ is $0.05 \mathrm{mg} / \mathrm{kg}$.

\section{Estimated Daily Intake (EDI)}

The degree of toxicity of heavy metals to humans depends upon the daily intake as described by Gebreyohannes \& Gebrekidan (2018) [23]. Table 7 shows the estimated daily intake of the cosmetic products considered in this study, with Manganese (Mn) showing the highest values in the face powder samples with $0.0000240 \mathrm{mg} / \mathrm{kg} / \mathrm{day}$, $0.0000240 \mathrm{mg} / \mathrm{kg} / \mathrm{day}$, and $0.00000903 \mathrm{mg} / \mathrm{kg} / \mathrm{day}$ for P2, P6, and P5 respectively.

\section{Health Risk Assessment (HRI)}

The HRI represents the harmful effects of the heavy metals present in the personal care products in which are used, the values of the HRI are presented in Table 8 . it has been stated in literature that when the value of HRI is less than 1, the use of its products or consumable is safe or it is said not to pose any health hazards but when is greater than 1 , there may be concerns for possible health risk associated with overexposure [24,23]. All the values of HRI for all the metals considered in this study are below 1 as presented in Table 9.

\section{CONCLUSION}

The results obtained in this study show the mean concentration of metals such as lead, cadmium, zinc, nickel, chromium, manganese and cobalt in personal care products (PCPs) commonly used in Akure. The levels of most metals in this study are lower than those in reported studies. Through investigation of some heavy metals in some PCPs in literature, it has indicated some heavy metals to be below the acceptable level while some are above but continuous use of PCPs may result in an increase in the trace quantity of the heavy metals in the human body, thus the use of PCPs may be considered as sources of toxic metal poisoning. Base on the health risk index, it can be said that the heavy metals pose no health risk to humans. Metal contamination of PCPs is from contamination of raw materials and the use of substandard raw material, lack of compliance by small scale manufacturer and lack of strict regulation.

This study recommends the need for continual monitoring of the presence of heavy metals in PCPs continually been used in Nigeria to avert heavy metal poisoning through dermal poisoning, especially vulnerable groups such as children and women. 


\section{International Journal of Engineering Applied Sciences and Technology, 2020 \\ Vol. 5, Issue 7, ISSN No. 2455-2143, Pages 218-226 \\ Published Online November 2020 in IJEAST (http://www.ijeast.com)}

Further studies on heavy metals in PCPs are recommended to keep PCPs in-check and should include other metals in different categories of PCPs commonly used in Nigeria to prevent associated heavy metal risks.

\section{Acknowledgements}

The authors are grateful to the laboratory Technologist, Mrs. Ibeto A.U who assisted in the research work.

\section{REFERENCE}

[1] Al-Dayel O., Hefne J., Al-Ajyan T. "Human exposure to heavy metal from cosmetics", Orient. Journal Chem. 27 (pp. 1-11), 2011.

[2] Reed S. "Cosmetics and your health". Department of Health and Human Services., 22-25, 2007.

[3] Oyedeji F., Hassan G., Adeleke B. "Hydroquinone and heavy metals levels in cosmetics marketed in Nigeria". Trends Applied. Science Resources, pp.622-639, 2011.

[4] Saha Rumpa, Mukherjee Kakali, Saha Indrajit, Ghosh Aniruddha, Ghosh Sumanta K, Saha Bidyut. "Removal of hexavalent chromium from water by adsorption on mosambi (Citrus limetta) peel". Res Chem Intermed, pp.2245-2257, 2013.

[5] Scragg A. (2006). Environmental Biotechnology. Oxford, Uk: Oxford University Press.

[6] Sainio E., Jolanki R., Hakala E., Kanerva L. "Metals and arsenic in eye shadows". contact Dermatitis, pp.5-10, 2000

[7] Koller K.T.B., Spurgeon L.L. "Recent developments in low-level lead exposure and intellectual impairment in children". Environment Health Perspect, (pp.987-994), 2004

[8] Adal A., and Tarabar A. (2013). Retrieved from http://emedicine.medscape.com/article/8149 60-overview

[9] Canada.ca (2012, July 26). Guidance on heavy metals impurities in cosmetics. Retrieved from http://www.canada.ca/en/healthcanada/services/consumer-productssafety/reports-publications/industryprofessional/guidance-heavy-metalimpurities-cosmetics.html
[10] Ullah H., Shamsa N., Fozia A.R., Amir W., Shumaila Z., Muhammad A., Ijaz A. "Comparative study of heavy metals content in cosmetic products of different countries marketed in Khyber Pakhtunkhwa", Pakistan. Arabian Journal of Chemistry, pp.10-18, 2017.

[11] Pachauri V., Flora S. "Chelation in Metal Intoxication". International Journal of Environmental Resources, pp.2745-2788, 2010

[12] Lilley S.G., Florence T.M., Stauber J.L. "The use of sweat to monitor lead absorption through the skin". Science Total Environmental. 76 (267), 278, 1988

[13] Manahan S. Toxicology Chemistry and Biochemistry. CRC Press, limited Liability Company (LLC), 2003

[14] Godwill A.E., Paschaline U.F., Friday N.N., Marian N.U. (2019, June 19). Mechanism and Health Effects of Heavy Metal Toxicity in Humans, Poisoning in the Modern World. Retrieved from https://www.intechopen.com: https://www.intechopen.com/books/poisonin g-in-the-modern-world-new-tricks-for-anold-dog-/mechanism-and-health-effects-ofheavy-metal-toxicity-in-humans

[15] White A.R., Huang X., Jobling M.F., Barrow C.J., Beyreuther K., Masters C.L., Bush A.I., Cappai R. "Homocysteine potentiates copper- and amyloid-beta peptide-mediated toxicity in primary neuronal cultures: possible risk factors in the Alzheimer's-type neurodegenerative pathways". Journal of Neurochemistry, pp.1509-1520, 2001

[16] Sayre L.M., Perry G., Harris P.L.R., Liu Y.H., Schubert K.A., Smith M.A. "In situ oxidative catalysis by neurofibrillary tangles and senile in Alzheimer's disease: a central role for bound transition metals". Journal of Neurochemistry. pp.270-279. 2000

[17] Health Canada. (2011, January). Consumer product safety: Draft guidance on heavy metal impurities in cosmetics. Retrieved from Health Canada: http://www.hescc.gc.ca/cpsspc/legislation/co nsultation/_ccosmt./metalmtauxconsulteng 


\section{International Journal of Engineering Applied Sciences and Technology, 2020 \\ Vol. 5, Issue 7, ISSN No. 2455-2143, Pages 218-226 \\ Published Online November 2020 in IJEAST (http://www.ijeast.com)}

[18] Bundesgesundheitsblatt (Federal Health Journal, Germany), (1985) .

[19] US FDA (2017, November 3). United State Food Drug \& Cosmetic Act on Prohibited \&

Restricted Ingredients in Cosmetics.

Retrieved from:

https://www.fda.gov/cosmetics/cosmeticslaws-regulations/prohibited-restrictedingredients-cosmetics

[20] Bocca B., Forte G., Petrucci F., Cristaudo, "A Levels of nickel and other potentially allergenic metals in Ni-tested commercial body creams". Journal of Pharmacology Biomedical Anal. pp.1197-1202, 2007

[21] Ayenimo J., Yusuf A., Adekunle A., Makinde O. "Heavy metals exposure from personal care products". Bulletin of Environmental Contamination and Toxicology, pp.8-14, 2010

[22] Aendo P., Thongyuan S, Songserm T, Tulayaku P. "Carcinogenic and non-carcinogenic risk assessment of heavy metals contamination in duck eggs and meat as a warning scenario in Thailand". Science of the Total Environment, pp.215-222, 2019

[23] Gebreyohannes F. and Gebrekidan A. "Health risk assessment of heavy metals via consumption of spinach vegetable grown in Elalla river". Bulletin Chemical Society. Ethiopia, pp.65-75, 2018

[24] Omenka S.S., Adebola A.A. "Heavy metal content of selected personal care products (PCPs) available in Ibadan, Nigeria, and their toxic effects". Toxicology Reports, pp.628635,2016

[25] Smith R.L. (1995). EPA Region III Risk Concentration Table. Pennsylvania: EPA.

[26] SCCS (Scientific Committee on Consumer Safety). "SCCS Notes of Guidance for the testing of cosmetic ingredients and their safety evaluation 10th revision". European Union., 2018

[27] Ali S., Maryam B., Fatima A.A. "Determination of some heavy metals in selected cosmetics products sold in Kano Metropolis, Nigeria". Toxicology Reported, pp.866-869, 2016

[28 Cosmetics info. (n.d). retrieved from http://cosmeticsinfo.org
[29] Vella A. and Attard E. Analysis of heavy metal content in conventional and herbal toothpaste available in Maltese Pharmacies. MDPI, pp.1-11, 2019

[30] Deshpande G. (2005). Handbook of food toxicology. UK: Taylor and Francis e-library.

[31] Al-weher M. "levels of heavy metals, $\mathrm{Cd}, \mathrm{Cu}$ and $\mathrm{Zn}$ in three fishes species collected from the Northern Joran valley". Jordan Journal of Biological Sciences, pp.47-52, 2008

[32] Nnoron I. "Trace metals in cosmetics facial talcum powder marketed in Nigeria". Toxicology Environmental Chemistry, pp.1135-1148, 2011.

[33] Nnorom C., Igwe J., Oji-Nnorom C. "Trace metal contents of facial (makeup) cosmetics commonly used in Nigeria". Africa Journal of Biotechnology, pp.1133-1138, 2005.

[34] US FDA (2020, March 5). United State Food Drug \& Cosmetic Act on Daily Value on the New Nutrition and Supplement Facts Label. Retrieved from: https://www.fda.gov/food/new-nutritionfacts-label/daily-value-new-nutrition-andsupplement-facts-labels

[35] Mayildurai R., Velmani N., Ramasubbi A. "Systematic investigation of heavy metals assay in Indian fashion jewelry". International Journal Science Technology, pp.8-16, 2015.

[36] Sani S., Shehu A. "Determination of some heavy metals concentration in selected detergents used in Kano metropolis, Nigeria". Environmental Toxicology Studies Journal. pp.4-7, 2018 